\title{
DFT study on Raman spectra of Fe(II)-porphin
}

\author{
V. A. Minaeva, B. F. Minaev, D. M. Hovorun'
}

Cherkasy Bohdan Khmelnytsky National University 81 Shevchenko blvd, Cherkasy 18031 Ukraine

${ }^{1}$ Institute of Molecular Biology and Genetics, NAS of Ukraine 150 Academician Zabolotny Str., Kyiv 03680 Ukraine

minaeva@cdu.edu.ua

\begin{abstract}
Density functional theory (DFT) quantum-chemical calculations of Raman spectra of Fe(II)-porphin in a quintet (ground) state were performed. Spin-unrestricted UB3LYP functional with the 6-311G basis was used for geometry optimization and Raman calculation. All active modes of Raman spectra were analyzed in detail. It was noted that the insertion of Fe(II) ion into porphin leads to the considerable changes in frequencies and intensities for those vibrational modes which involve nitrogen atoms displacement. The Raman depolarization ratio for plane polarized incident light is discussed.
\end{abstract}

Keywords: Fe(II)-porphin, quintet spin state, DFT, Raman spectra

Introduction. The iron ion with the $(+2)$ degree of oxidation plays an important role in chemistry of hemproteins, in binding of oxygen and its activation in particular. $\mathrm{Fe}(\mathrm{II})$-porphin (Fe(II)P) may exist either in high-spin $(\mathrm{S}=2)$, or low-spin $(\mathrm{S}=0)$ state, or in a state with interim spin $(S=1)$, where $S$ is a quantum number of the total spin. The DFT quantum-chemical calculations of spin states of Fe(II)-porphin molecule were performed as in [1] with subsequent determination of relationship between a spin and stereochemistry of $\mathrm{Fe}(\mathrm{II})$-porphin which is of great importance for understanding biological functions of hemproteins. It was noted that the quintet $(Q)$ state with a quantum number $\mathrm{S}=2$ is the main ground state of $\mathrm{Fe}(\mathrm{II}) \mathrm{P}$ molecule.
The data on the force field of vibrations of all atoms in $\mathrm{Fe}(\mathrm{II})$-porphin molecule are necessary to reveal mechanisms of catalytic processes, occurring with participation of these and related molecules, as vibrational frequencies determine the energy transfer and reaction capacity of hemoproteins in the interaction with ligands as well as in the enzymatic reactions of cytochrome $\mathrm{P} 450$, for which $\mathrm{Fe}(\mathrm{II}) \mathrm{P}$ is a simple model. DFT was used to calculate infrared (IR) spectrum of absorption and Raman spectra of a free-base porphin $\left(\mathrm{H}_{2} \mathrm{P}\right)$ in $[2,3]$, and IR-spectrum of $\mathrm{Fe}(\mathrm{II})$-porphin in different spin states - in [4].

The current work deals with DFT quantum-chemical calculations ofRaman spectra of $\mathrm{Fe}(\mathrm{II})$-porphin in the quintet (ground) state. Special 
attention is paid to the analysis of form of vibrational modes which belong to various types of symmetry.

In case of the $\mathrm{Fe}$ (II)P molecule with high symmetry $\left(D_{2 h}\right)$, the normal vibrations active in Raman spectra are prohibited in IR-spectrum, and vice versa, the intense IR-bands are absent in Raman spectra. Therefore, this work devoted to the theory of Raman spectra of Fe(II)P is a supplement to the work [4], where vibrations, active inRaman spectra, were not considered.

It is especially important to determine force constants for the out-of-plane vibrations of Fe ion, dependent on the balance of attractions and repulsions due to conjugation of the $4 \mathrm{p}_{\pi}(\mathrm{Fe})-$ and $a_{2 \mathrm{u}}$ (porphin) orbitals as well as the antibinding $3 d_{x^{2}-y^{2}}(\mathrm{Fe})$ and $2 p(N)$-combinations of orbitals. The issue of changes in strength of chemical bonds depending on $\pi$-delocalization, $d-\pi$-conjugation, and spin of Fe ion is yet to be clarified. These questions are essential for understanding enzyme activity of cytochromes and hemoproteins.

Investigations of molecular vibrational spectra using quantum-chemical calculations have recently become more popular [1-10]. Frequencies of the IR spectrum of $\mathrm{Fe}(\mathrm{II}) \mathrm{P}$ were calculated by Kozlowski et alt. [5] using DFT B3LYP method with the 6-31G basis set, however, only several normal modes of the low-frequency vibrations were presented and discussed. The majority of frequency assignments in Raman spectra of cytochromes and metalloporphyrins were made on the basis of empiric rules and fitting [11-13]. Therefore, the authors consider the calculations of Fe-porphyrins spectra on the ground of consistent theoretical approach to be quite urgent and timely.

Materials and Methods. The DFT method [6, 14] was used in this work to perform calculations of the optimized geometry and Raman spectra of the Fe(II)P molecule at the B3LYP level of theory (three-parameter hybride exchange-correlation functional of Becke-Lee-Yang-Parr approach [6]) with the 6-311G basis set $[14,15]$ using GAUSSIAN 03 software package [15]. Frequencies were obtained by analytical calculations of the Hessian matrix for the equilibrium geometry, optimized in different spin states.

IR and Raman spectra of four-coordinated $\mathrm{Fe}(\mathrm{II})$-porphin have not been studied in experiments due to chemical instability of Fe(II)P depending on fast oxidation [16]. There are data on resonance Raman spectra of five- and six-coordinated derivatives of $\mathrm{Fe}(\mathrm{II})$-octaethylporphyrin (FeOEP), namely, $\mathrm{Fe}(\mathrm{OEP}) \mathrm{Br}, \quad\left[\mathrm{Fe}(\mathrm{OEP})\left(\right.\right.$ dimethyl sulfoxide) $\left.{ }_{2}\right] \mathrm{ClO}_{4}$, $\mathrm{Fe}(\mathrm{OEP})(\text { imidazol })_{2}[7,11]$ etc. It was shown for fiveand six-coordinated metalloporphyrins [11] that vibrations of metal-axial ligand bonds do not blend with vibrations of macrocycle. Therefore, it is possible to compare corresponding Raman and IR bands of FeP to spectra of $\mathrm{Fe}(\mathrm{OEP})$ derivatives. We consider it critical to clarify IR and Raman spectra of idealized FeP structures in different spin states and degrees of Fe oxidation, comparing results of calculations of vibrations of $\mathrm{FeP}$ to analogous results for free-base porphin $\left(\mathrm{H}_{2} \mathrm{P}\right)$ and zink-porphin $(\mathrm{ZnP})$, reliable assignment of IR and Raman spectra as well as all non-active vibrations for which have already been obtained on the basis of rather accurate DFT calculations for the ground singlet state of these molecules $[3,8-10]$. This is the only way to decipher vibrational spectra of actual hemproteins and to determine dependence of frequencies and force fields on spin and degree of the Fe ion oxidation.

Though calculations of normal vibrations of metalloporphyrins on the basis of empirical force fields $[12,13]$ provide many assignments for in-plane modes and specify a number of regularities in IR and Raman spectra without analysis of their intensities, they can not provide a definite answer to abovementioned questions, that can be solved only by direct DFT calculation.

Results and Discussion. The Fe(II)P molecule in the quintet state possesses the $D_{2 h}$ symmetry, but its structure is similar to the $D_{4 h}$ symmetry, which this molecule has in the singlet (S) and triplet (T) states. The $D_{4 h}$ point group has two kinds of symmetry $-A_{l g}$ and $B_{I g}$, which correspond to $A_{g}$ - one irreducible representation in the $D_{2 h}$ group. Vibrations of this type of the $\mathrm{Fe}(\mathrm{II}) \mathrm{P}$ molecule in the quintet state correlate with two types of symmetry $-A_{l g}$ and $B_{l g}$ in the S- and T-states in the $D_{4 h}$ point group, thus they have different polarization. The lines in Raman spectra with $0<$ $\rho<3 / 4$, are called polarized [17]. The polarization degree is high (e.g. $\rho=0.11)$ only for those vibrations of the $A_{g}$-type in the Fe(II)P molecule in quintet state, 


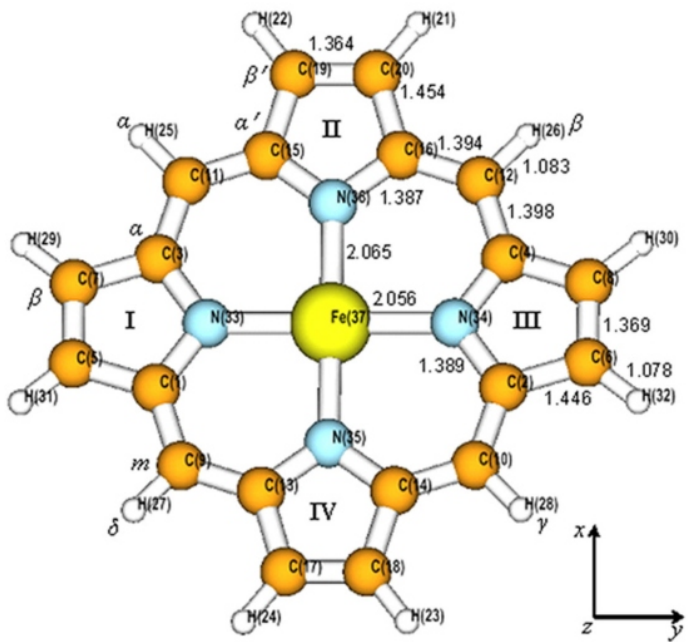

Fig.1. Indication of atoms and the choice of axes in the $\mathrm{Fe}(\mathrm{II})$-porphin molecule in the quintet state (bond distances are presented in $\dot{A}$ )

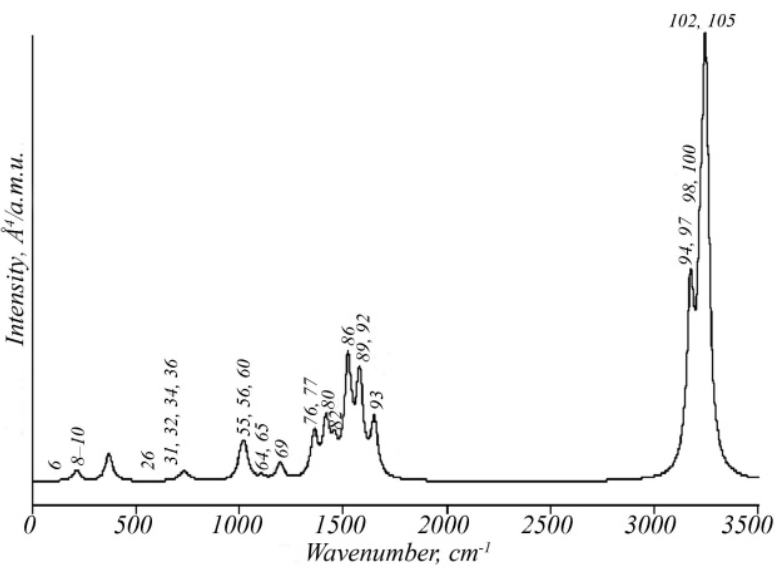

Fig.2.Raman spectra of the Fe(II)-porphin molecule in the quintet state, calculated by B3LYP/6-311G method without consideration of the scaling factor (intensity maximum $1038.8 \mathrm{~A}^{4} /$ a.m.u.; the Lorenz form for the line was used to simulate the band profile, a half-width of bands is equal to $20 \mathrm{~cm}^{-1}$ ).

which correlate with $A_{I g}$ vibrations in the $D_{4 h}$ group (see Table 1 in [4]). These data are important for band assignment in Raman spectra and their comparative analysis for all hemproteins.

Numeration of atoms and the choice of axes in $\mathrm{Fe}(\mathrm{II}) \mathrm{P}$ molecule ( $\mathrm{Oz}$ axis is perpendicular to the molecular plane) are shown in Fig. 1. We used traditional marking system: carbon atoms in $\alpha$-positions $-\mathrm{C}_{\alpha}$, in $\beta$-positions $-\mathrm{C}_{\beta}$, in mezo-positions of macrocycle $-\mathrm{C}_{\mathrm{m}}$, mezo-atoms of hydrogen, located close to bridge carbon atoms, correspond to Greek letters $\alpha, \beta, \gamma, \delta$. Atoms of pyrrole rings II and IV are indicated with prime symbols $\left(\mathrm{C}_{\alpha}{ }^{\prime}, \mathrm{C}_{\beta}{ }^{\prime}\right)$. Calculations showed that in the quintet state of the $\mathrm{Fe}$ (II)P molecule all atoms are located in one plane with simultaneous in-plane deformation of the molecule (compared to the singlet and triplet states) and its symmetry decreases from $D_{4 h}$ to $D_{2 h}$ [1]. Electronic state of spin quintet has ${ }^{5} B_{2 g}$ symmetry.

Calculated bond distances, presented in Fig. 1, show that if a molecule rotates around the $\mathrm{Oz}$ axis in $90^{\circ}$, the bond distances differ from the initial ones, which testifies to decrease the symmetry to $D_{2 h}$.

The Fe(II)P molecule has 37 atoms and 105 internal freedom degrees. If axes are selected as in Fig.1, in the $D_{2 h}$-symmetry 105 normal vibrations are distributed in the symmetry types as follows: $18 a_{g}, 17 b_{1 g}, 8 b_{2 g}, 8 b_{3 g}$, $8 a_{u}, 10 b_{1 u}, 18 b_{2 u}, 18 b_{3 u}$, where $a_{g}, b_{l g}, b_{3 u}$, and $b_{2 u}$ - are plane vibrations, while $b_{3 g}, b_{2 g}, a_{u}$, and $b_{l u}$ are out-of-plane vibrations.

Symmetry vibrations of the $b_{1 u}, b_{2 u}$, and $b_{3 u}$ types are allowed in the IR spectrum, simulated by us and analysed in Ref. [4].Raman spectra of Fe(II)P, calculated in the current work, has 51 normal vibrations: 18 vibrations of $a_{g}$ symmetry, $17-b_{1 g}$ symmetry, $8-b_{2 g}$, and $8-$ $b_{3 g}$ symmetry. Calculated frequencies and forms of normal vibrations, active in Raman spectra of $\mathrm{Fe}(\mathrm{II}) \mathrm{P}$, are presented in Table, which also gives comparison with Raman spectra of $\mathrm{H}_{2} \mathrm{P}$ (all frequencies of normal vibrations are real). Fig. 2 presents calculated Raman spectra of $\mathrm{Fe}(\mathrm{II}) \mathrm{P}$.

Molecular symmetry does not change in the course of formation of $\mathrm{Fe}$ (II)P in the quintet state from porphin, since there is no alignment of geometrical parameters of pyrrole fragments, observed in metallocomplex Fe(II)P (Fig. 1). Raman spectra of $\mathrm{Fe}(\mathrm{II}) \mathrm{P}$, compared to that of $\mathrm{H}_{2} \mathrm{P}$, will not contain vibrational modes, determined by valence vibrations of the $\mathrm{N}-\mathrm{H}$ bond in $\mathrm{H}_{2} \mathrm{P}\left(\mathrm{v}_{\text {calc }}=3584 \mathrm{~cm}^{-1}\right)$ and deformational $\mathrm{NH}$-vibrations $\left(v_{\text {calc }}=610\right.$ and $\left.1261 \mathrm{~cm}^{-1}\right)$.

The high-frequency region of Raman spectra. We predicted a number of very intense Raman bands in high-frequency region which are determined by $\mathrm{CH}$-vibrations (Table). This range of porphyrin spectra has not been studied in experiments, as it is covered by scattering due to $\mathrm{CH}$ - or $\mathrm{OH}$-vibrations. However, it provides a lot of interesting information if a proper assignment is available. 
Frequencies $\left(v, \mathrm{~cm}^{-1}\right)$ and intensities (I, $\dot{\mathrm{A}}^{4} /$ a.m.u.) of normal vibrations in Raman spectra of Fe(II)-porphin and free-base porphin, calculated by the B3LYP/6-311G method.

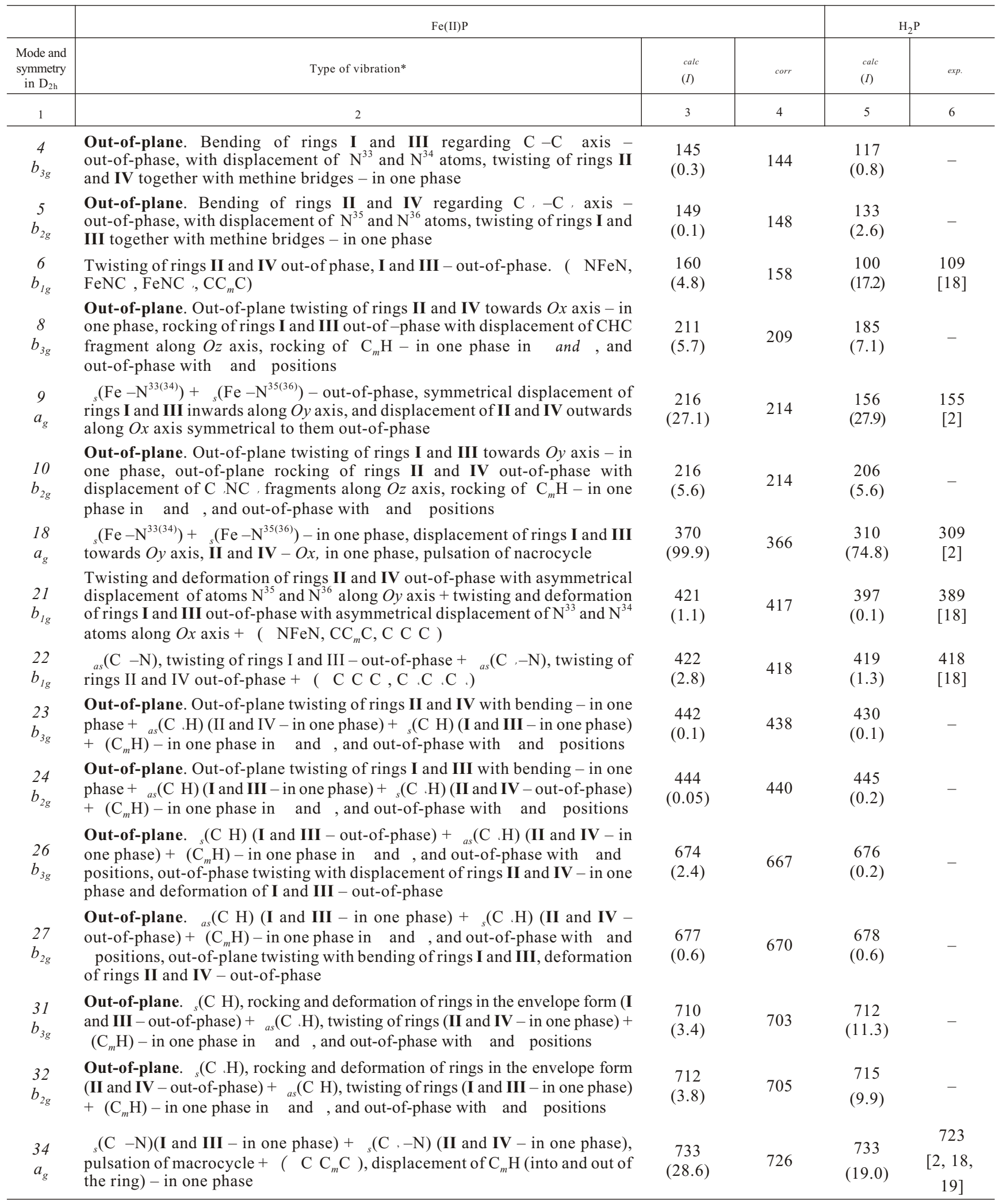




\begin{tabular}{|c|c|c|c|c|c|}
\hline 1 & 2 & 3 & 4 & 5 & 6 \\
\hline $\begin{array}{l}36 \\
a_{g}\end{array}$ & $\begin{array}{l}v_{s}\left(\mathrm{Fe}-\mathrm{N}^{33(34)}\right)+v_{s}\left(\mathrm{Fe}-\mathrm{N}^{35(36)}\right)-\text { out-of-phase }+v_{s}\left(\mathrm{C}_{\alpha}-\mathrm{N}\right)(\mathbf{I} \text { and } \mathbf{I I I}-\text { in one } \\
\text { phase })+v_{s}\left(\mathrm{C}_{\alpha^{\prime}}-\mathrm{N}\right)(\mathbf{I I} \text { and } \mathbf{I V}-\text { out-of-phase }) \text {, pulsation of rings }+\delta(\angle \mathrm{CNC})+ \\
r\left(\mathrm{C}_{m} \mathrm{H}\right)+r\left(\mathrm{C}_{\beta} \mathrm{H}\right)+r\left(\mathrm{C}_{\beta} \cdot \mathrm{H}\right)\end{array}$ & $\begin{array}{l}756 \\
(6.3)\end{array}$ & 748 & $\begin{array}{c}740 \\
(12.5)\end{array}$ & $\begin{array}{l}736 \\
{[18]}\end{array}$ \\
\hline $\begin{array}{l}39 \\
b_{2 g}\end{array}$ & $\begin{array}{l}\text { Out-of-plane. } \gamma_{s}\left(\mathrm{C}_{\beta} \cdot \mathrm{H}\right) \text {, deformation of rings in the envelope form (II and } \mathbf{I V}- \\
\text { out-of-phase) }+\gamma\left(\mathrm{C}_{m} \mathrm{H}\right) \text {-in one phase in } \alpha \text { and } \beta \text {, and out-of-phase with } \gamma \text { and } \delta \\
\text { positions }\end{array}$ & $\begin{array}{l}800 \\
(2.9)\end{array}$ & 784 & $\begin{array}{l}789 \\
(3.1)\end{array}$ & - \\
\hline $\begin{array}{l}40 \\
b_{3 g}\end{array}$ & $\begin{array}{l}\text { Out-of-plane. } \gamma_{s}\left(\mathrm{C}_{\beta} \mathrm{H}\right) \text {, deformation of rings in the envelope form (I and III- } \\
\text { out-of-phase) }+\gamma\left(\mathrm{C}_{m} \mathrm{H}\right) \text {-in one phase in } \alpha \text { and } \delta \text {, and out-of-phase with } \beta \text { and } \gamma \\
\text { positions }\end{array}$ & $\begin{array}{l}804 \\
(2.0)\end{array}$ & 788 & $\begin{array}{l}789 \\
(4.8)\end{array}$ & - \\
\hline $\begin{array}{l}43 \\
b_{1 g}\end{array}$ & $\begin{array}{l}\delta\left(\angle \mathrm{C}_{\beta} \mathrm{C}_{\alpha} \mathrm{N}, \mathrm{C}_{\alpha} \mathrm{C}_{\beta} \mathrm{C}_{\beta}, \mathrm{C}_{\beta} \cdot \mathrm{C}_{\alpha}, \mathrm{N}, \mathrm{C}_{\alpha} \cdot \mathrm{C}_{\beta} \cdot \mathrm{C}_{\beta} \cdot\right), \text { twisting and deformation of rings }+ \\
\tau\left(\mathrm{C}_{m} \mathrm{H}\right)+\tau\left(\mathrm{C}_{\beta} \mathrm{H}\right)+\tau\left(\mathrm{C}_{\beta}, \mathrm{H}\right)\end{array}$ & $\begin{array}{l}826 \\
(0.0)\end{array}$ & 809 & $\begin{array}{l}800 \\
(1.2)\end{array}$ & $\begin{array}{l}786 \\
{[18,19]}\end{array}$ \\
\hline $\begin{array}{l}45 \\
b_{1 g}\end{array}$ & $\begin{array}{l}v_{a s}\left(\mathrm{C}_{\alpha}-\mathrm{N}\right)+v_{a s}\left(\mathrm{C}_{\alpha^{\prime}}-\mathrm{N}\right) \text {, twisting and deformation of rings (I, III - } \\
\text { out-of-phase, III, IV }- \text { out-of-phase })+\delta\left(\angle \mathrm{C}_{\beta} \mathrm{C}_{\alpha} \mathrm{N}, \mathrm{C}_{\alpha} \mathrm{C}_{\beta} \mathrm{C}_{\beta}, \mathrm{C}_{\beta} \cdot \mathrm{C}_{\alpha} \mathrm{N}, \mathrm{C}_{\alpha} \cdot \mathrm{C}_{\beta} \cdot \mathrm{C}_{\beta} \cdot\right) \\
+\tau\left(\mathrm{C}_{m} \mathrm{H}\right)+\tau\left(\mathrm{C}_{\beta} \mathrm{H}\right)+\tau\left(\mathrm{C}_{\beta}, \mathrm{H}\right)\end{array}$ & $\begin{array}{l}847 \\
(0.2)\end{array}$ & 830 & $\begin{array}{l}821 \\
(1.5)\end{array}$ & $\begin{array}{l}805 \\
{[18]}\end{array}$ \\
\hline $\begin{array}{l}47 \\
b_{3 g}\end{array}$ & $\begin{array}{l}\text { Out-of-plane. } \gamma\left(\mathrm{C}_{m} \mathrm{H}\right)-\text { in one phase in } \alpha \text { and } \delta \text {, and out-of-phase with } \beta \text { and } \gamma \\
\text { positions }+\gamma_{s}\left(\mathrm{C}_{\beta} \mathrm{H}\right)(\mathbf{I} \text { and } \mathbf{I I I}-\text { out-of-phase })+\gamma_{a s}\left(\mathrm{C}_{\beta} \cdot \mathrm{H}\right) \text { (II and } \mathbf{I V}-\text { in one } \\
\text { phase) }\end{array}$ & $\begin{array}{l}892 \\
(0.1)\end{array}$ & 874 & $\begin{array}{l}866 \\
(2.4)\end{array}$ & - \\
\hline $\begin{array}{l}48 \\
b_{2 g}\end{array}$ & $\begin{array}{l}\text { Out-of-plane. } \gamma\left(\mathrm{C}_{m} \mathrm{H}\right)-\text { in one phase in } \alpha \text { and } \beta \text {, and out-of-phase with } \gamma \text { and } \delta \\
\text { positions }+\gamma_{s}\left(\mathrm{C}_{\beta} \cdot \mathrm{H}\right)(\mathbf{I I} \text { and } \mathbf{I V}-\text { out-of-phase })+\gamma_{a s}\left(\mathrm{C}_{\beta} \mathrm{H}\right)(\mathbf{I} \text { and } \mathbf{I I I}-\text { in one phase })\end{array}$ & $\begin{array}{l}892 \\
(0.3)\end{array}$ & 874 & $\begin{array}{l}865 \\
(1.4)\end{array}$ & - \\
\hline $\begin{array}{l}51 \\
b_{3 g}\end{array}$ & $\begin{array}{l}\text { Out-of-plane. } \gamma_{a s}\left(\mathrm{C}_{\beta} \cdot \mathrm{H}\right)(\mathbf{I I} \text { and } \mathbf{I V}-\text { in one phase })+\gamma\left(\mathrm{C}_{m} \mathrm{H}\right)-\text { in one phase in } \alpha \\
\text { and } \delta \text {, and out-of-phase with } \beta \text { and } \gamma \text { positions }+\gamma_{s}\left(\mathrm{C}_{\beta} \mathrm{H}\right) \text { (I and III - } \\
\text { out-of-phase) }\end{array}$ & $\begin{array}{l}939 \\
(0.1)\end{array}$ & 920 & $\begin{array}{l}917 \\
(0.9)\end{array}$ & - \\
\hline $\begin{array}{l}52 \\
b_{2 g}\end{array}$ & $\begin{array}{l}\text { Out-of-plane. } \gamma_{s}\left(\mathrm{C}_{\beta} \cdot \mathrm{H}\right)(\mathbf{I I} \text { and } \mathbf{I V}-\text { out-of-phase })+\gamma\left(\mathrm{C}_{m} \mathrm{H}\right)-\text { in one phase in } \alpha \\
\text { and } \beta \text {, and out-of-phase with } \gamma \text { and } \delta \text { positions }+\gamma_{a s}\left(\mathrm{C}_{\beta} \mathrm{H}\right)(\mathbf{I} \text { and } \mathbf{I I I}-\text { in one phase })\end{array}$ & $\begin{array}{l}940 \\
(0.01)\end{array}$ & 921 & $\begin{array}{l}920 \\
(0.7)\end{array}$ & - \\
\hline $\begin{array}{l}55 \\
a_{g}\end{array}$ & $\begin{array}{l}v_{s}\left(\mathrm{Fe}-\mathrm{N}^{35(36)}\right)+v_{s}\left(\mathrm{C}_{\alpha^{\prime}}-\mathrm{C}_{\beta}\right)(\mathbf{I I} \text { and } \mathbf{I V}-\text { in one phase })+v_{s}\left(\mathrm{C}_{\alpha}-\mathrm{C}_{\beta}\right)(\mathbf{I} \text { and } \mathbf{I I I}- \\
\text { in o ne phase })+\delta\left(\angle \mathrm{C}_{\alpha^{\prime}} \mathrm{C}_{\beta} \cdot \mathrm{H}, \mathrm{C}_{\beta} \cdot \mathrm{C}_{\beta} \cdot \mathrm{H}\right)\end{array}$ & $\begin{array}{l}1008 \\
(34.1)\end{array}$ & 988 & $\begin{array}{l}973 \\
(88.3)\end{array}$ & $\begin{array}{l}952 \\
{[2,18} \\
19]\end{array}$ \\
\hline $\begin{array}{l}56 \\
b_{1 g}\end{array}$ & $\begin{array}{l}\delta(\angle \mathrm{NFeN})+v_{a s}\left(\mathrm{C}_{\alpha}-\mathrm{N}\right)(\mathbf{I} \text { and } \mathbf{I I I}-\text { out-of-phase })+v_{a s}\left(\mathrm{C}_{\alpha^{\alpha}}-\mathrm{N}\right)(\mathbf{I I} \text { and } \mathbf{I V}- \\
\text { out-of-phase), strong displacement of } \mathrm{N} \text { atoms, twisting of rings }+\tau\left(\mathrm{C}_{\beta} \mathrm{H}\right)+\tau\left(\mathrm{C}_{\beta} \cdot \mathrm{H}\right)\end{array}$ & $\begin{array}{c}1012 \\
(57.5)\end{array}$ & 992 & $\begin{array}{l}995 \\
(5.1)\end{array}$ & $\begin{array}{l}976 \\
{[18]} \\
972 \\
{[19]}\end{array}$ \\
\hline $\begin{array}{l}57 \\
b_{1 g}\end{array}$ & $\begin{array}{l}v_{a s}\left(\mathrm{C}_{\alpha^{\prime}}-\mathrm{N}\right) \text { and } v_{a s}\left(\mathrm{C}_{\alpha^{\prime}}-\mathrm{C}_{\beta^{\prime}}\right)(\mathbf{I I} \text { and } \mathbf{I V}-\text { out-of-phase })+v_{a s}\left(\mathrm{C}_{\alpha}-\mathrm{N}\right) \text { and } \\
v_{a s}\left(\mathrm{C}_{\alpha}-\mathrm{C}_{\beta}\right)(\mathbf{I} \text { and } \mathbf{I I I}-\text { out-of-phase }) \text {, twisting of rings }+\delta\left(\angle \mathrm{C}_{\alpha} \mathrm{C}_{\beta} \mathrm{H}, \mathrm{C}_{\alpha^{\prime}} \mathrm{C}_{\beta} \cdot \mathrm{H}\right)+ \\
\tau\left(\mathrm{C}_{\beta} \mathrm{H}\right)+\tau\left(\mathrm{C}_{\beta^{\prime}} \mathrm{H}\right)\end{array}$ & $\begin{array}{l}1014 \\
(1.2)\end{array}$ & 994 & $\begin{array}{l}1024 \\
(8.6)\end{array}$ & $\begin{array}{c}1005 \\
{[18,19]}\end{array}$ \\
\hline $\begin{array}{l}60 \\
a_{g}\end{array}$ & $\begin{array}{l}v_{s}\left(\mathrm{Fe}-\mathrm{N}^{33(34)}\right)+v_{s}\left(\mathrm{C}_{\alpha}-\mathrm{C}_{\beta}\right)(\mathbf{I} \text { and } \mathbf{I I I}-\text { in one phase }) \text {, pulsation of rings }+ \\
\delta\left(\angle \mathrm{C}_{\alpha} \mathrm{C}_{\beta} \mathrm{H}, \mathrm{C}_{\beta} \mathrm{C}_{\beta} \mathrm{H}\right)+v_{s}\left(\mathrm{Fe}-\mathrm{N}^{35(36)}\right)+v_{s}\left(\mathrm{C}_{\alpha^{c}}-\mathrm{C}_{\beta} \cdot\right)(\mathbf{I I} \text { and } \mathbf{I V})\end{array}$ & $\begin{array}{c}1027 \\
(77.4)\end{array}$ & 1006 & $\begin{array}{c}1010 \\
(43.6)\end{array}$ & $\begin{array}{l}987 \\
988 \\
{[2]}\end{array}$ \\
\hline $\begin{array}{l}64 \\
a_{g}\end{array}$ & $\begin{array}{l}r\left(\mathrm{C}_{\beta} \mathrm{H}\right)+r\left(\mathrm{C}_{\beta} \cdot \mathrm{H}\right)+v\left(\mathrm{C}_{\beta}-\mathrm{C}_{\beta}\right)(\mathbf{I} \text { and } \mathbf{I I I}-\text { in one phase })+v\left(\mathrm{C}_{\beta} \cdot-\mathrm{C}_{\beta}\right)(\mathbf{I I} \text { and } \mathbf{I V} \\
- \text { in one phase, but out-of-phase with } \mathbf{I} \text { and } \mathbf{I I I})\end{array}$ & $\begin{array}{l}1102 \\
(4.2)\end{array}$ & 1080 & $\begin{array}{l}1078 \\
(0.7)\end{array}$ & $\begin{array}{c}1063 \\
{[18,19]}\end{array}$ \\
\hline $\begin{array}{l}65 \\
a_{g}\end{array}$ & $\begin{array}{l}r\left(\mathrm{C}_{\beta} \mathrm{H}\right)+r\left(\mathrm{C}_{\beta} \cdot \mathrm{H}\right)+v\left(\mathrm{C}_{\beta}-\mathrm{C}_{\beta}\right) \text { and } v\left(\mathrm{C}_{\beta}, \mathrm{C}_{\beta}\right)-\text { in one phase }+\delta\left(\angle \mathrm{CC}_{\beta} \mathrm{H},\right. \\
\left.\mathrm{CC}_{\beta} \cdot \mathrm{H}\right) \text {, pulsation of rings in one phase }\end{array}$ & $\begin{array}{l}1107 \\
(9.1)\end{array}$ & 1085 & $\begin{array}{l}1085 \\
(6.1)\end{array}$ & $\begin{array}{l}1064 \\
{[2,]}\end{array}$ \\
\hline $\begin{array}{l}67 \\
b_{1 g}\end{array}$ & $\begin{array}{l}v_{a s}\left(\mathrm{C}_{\alpha}-\mathrm{N}\right) \text { and } v_{a s}\left(\mathrm{C}_{\alpha}-\mathrm{C}_{\beta}\right)(\mathbf{I} \text { and } \mathbf{I I I}-\text { out-of-phase })+v_{a s}\left(\mathrm{C}_{\alpha}-\mathrm{N}\right) \text { and } \\
v_{a s}\left(\mathrm{C}_{\alpha^{\prime}}-\mathrm{C}_{\beta}\right)(\mathbf{I I} \text { and } \mathbf{I V}-\text { out-of-phase }) \text {, deformation of rings }+r(\mathrm{CH})\end{array}$ & $\begin{array}{l}1174 \\
(1.7)\end{array}$ & 1151 & $\begin{array}{l}1161 \\
(0.1)\end{array}$ & $\begin{array}{l}1138 \\
{[18]}\end{array}$ \\
\hline $\begin{array}{l}69 \\
a_{g}\end{array}$ & $\begin{array}{l}r\left(\mathrm{C}_{m} \mathrm{H}\right)+v_{s}\left(\mathrm{C}_{\alpha^{c}}-\mathrm{N}\right) \text { and } v_{s}\left(\mathrm{C}_{\alpha^{c}}-\mathrm{C}_{\beta^{\prime}}\right)(\mathbf{I I} \text { and } \mathbf{I V}-\text { in one phase })+v_{s}\left(\mathrm{Fe}-\mathrm{N}^{33(34)}\right) \\
+v_{s}\left(\mathrm{Fe}-\mathrm{N}^{35(36)}\right)-\text { out-of-phase }+v_{s}\left(\mathrm{C}_{\alpha}-\mathrm{N}\right) \text { and } v_{s}\left(\mathrm{C}_{\alpha}-\mathrm{C}_{\beta}\right)(\mathbf{I} \text { and } \mathbf{I I I}-\text { in one } \\
\text { phase, but out-of-phase with II and } \mathbf{I V})+\delta\left(\angle \mathrm{CC}_{m} \mathrm{H}\right)\end{array}$ & $\begin{array}{c}1196 \\
(59.2)\end{array}$ & 1172 & $\begin{array}{l}1203 \\
(37.6)\end{array}$ & $\begin{array}{c}1177 \\
{[2,19]}\end{array}$ \\
\hline $\begin{array}{l}70 \\
b_{1 g}\end{array}$ & $\begin{array}{l}v_{a s}\left(\mathrm{C}_{\alpha^{\prime}}-\mathrm{N}\right) \text { and } v_{a s}\left(\mathrm{C}_{\alpha^{c}}-\mathrm{C}_{\beta}\right)(\mathbf{I I} \text { and } \mathbf{I V}-\text { out-of-phase })+\tau\left(\mathrm{C}_{\beta} \cdot \mathrm{H}\right)+v_{a s}\left(\mathrm{C}_{\alpha}-\mathrm{N}\right) \text { and } \\
v_{a s}\left(\mathrm{C}_{\alpha}-\mathrm{C}_{\beta}\right)(\mathbf{I} \text { and } \mathbf{I I I}-\text { out-of-phase })+\tau\left(\mathrm{C}_{\beta} \mathrm{H}\right)+\delta\left(\angle \mathrm{CC}_{m} \mathrm{C}, \mathrm{CC}_{\beta} \mathrm{H}\right)+v_{s}\left(\mathrm{C}_{m}-\mathrm{C}_{\alpha}\right)\end{array}$ & $\begin{array}{l}1220 \\
(0.9)\end{array}$ & 1196 & $\begin{array}{l}1213 \\
(1.6)\end{array}$ & $\begin{array}{l}1182 \\
{[18]}\end{array}$ \\
\hline $\begin{array}{l}75 \\
b_{1 g}\end{array}$ & $\begin{array}{l}\tau\left(\mathrm{C}_{\beta} \mathrm{H}\right)+\tau\left(\mathrm{C}_{\beta} \cdot \mathrm{H}\right)+v_{a s}\left(\mathrm{C}_{\alpha^{c}}-\mathrm{N}\right) \text { and } v_{a s}\left(\mathrm{C}_{\alpha^{\natural}}-\mathrm{C}_{\beta^{\prime}}\right)(\mathrm{II} \text { and IV }- \text { out-of-phase })+ \\
v_{a s}\left(\mathrm{C}_{\alpha}-\mathrm{N}\right) \text { and } v_{a s}\left(\mathrm{C}_{\alpha}-\mathrm{C}_{\beta}\right)\left(\mathrm{I} \text { and III }- \text { out-of-phase), twisting of rings }+\delta\left(\mathrm{C}_{m} \mathrm{H}\right)\right. \\
- \text { in one phase in } \alpha \text { and } \gamma, \text { and out-of-phase with } \beta \text { and } \delta \text { positions }+\delta\left(\angle \mathrm{CC}_{m} \mathrm{H}\right)\end{array}$ & $\begin{array}{l}1355 \\
(1.5)\end{array}$ & 1328 & $\begin{array}{c}1342 \\
(55.7)\end{array}$ & $\begin{array}{c}1313 \\
{[2]} \\
1316 \\
{[19]}\end{array}$ \\
\hline $\begin{array}{l}76 \\
a_{g}\end{array}$ & $\begin{array}{l}v_{s}\left(\mathrm{C}_{\alpha}-\mathrm{N}\right) \text { and } v_{s}\left(\mathrm{C}_{\alpha^{\prime}}-\mathrm{N}\right)-\text { in one phase }+v_{s}\left(\mathrm{C}_{\alpha}-\mathrm{C}_{\beta}\right) \text { and } v_{s}\left(\mathrm{C}_{\alpha^{\natural}}-\mathrm{C}_{\beta^{\prime}}\right)-\text { in one } \\
\text { phase }+\delta\left(\angle \mathrm{C}_{\alpha} \mathrm{C}_{m} \mathrm{C}_{\alpha^{\prime}}, \mathrm{CC}_{m} \mathrm{H}\right) \text {, deformation of rings, } \delta\left(\mathrm{C}_{m} \mathrm{H}\right)\end{array}$ & $\begin{array}{l}1360 \\
(57.5)\end{array}$ & 1333 & $\begin{array}{l}1382 \\
(42.2)\end{array}$ & $\begin{array}{c}1353 \\
{[2,18]} \\
1360 \\
{[19]}\end{array}$ \\
\hline
\end{tabular}




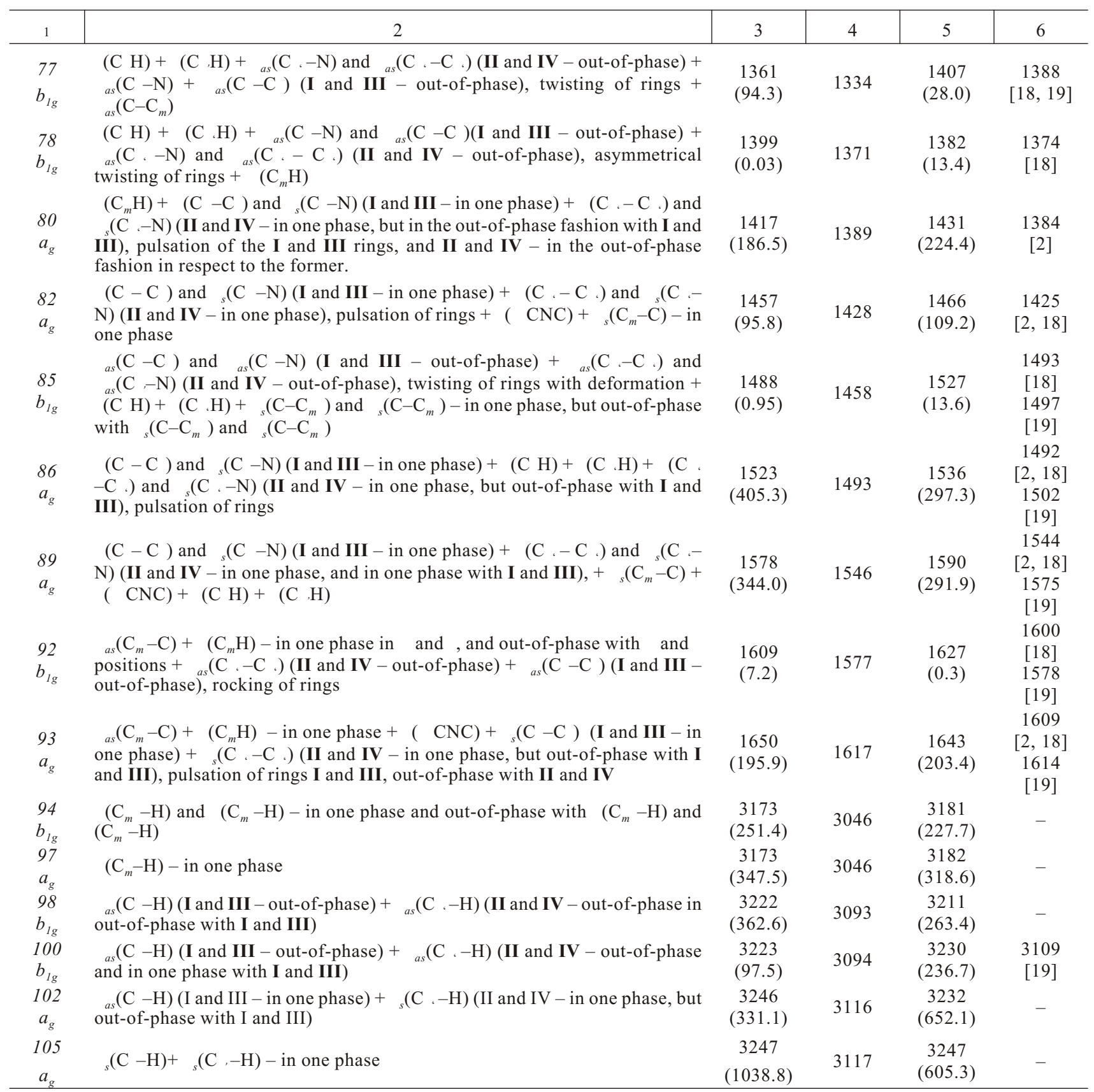

Note: *Stretching motions $(v): v_{\mathrm{s}}$ - symmetrical; $v_{\mathrm{as}}$ - asymmetrical. Deformational vibrations: $\delta(\angle)$ - change in valency angle; $\tau$ - twisting; $\mathrm{r}$ - rocking; $\delta(\mathrm{CH})$ - in-plane vibration of $\mathrm{CH}$-groups; $\gamma(\mathrm{CH})$ - out-of-plane vibration of $\mathrm{CH}$-groups

There are three vibrational modes of $a_{g}$ - and three modes of $b_{l g}$-symmetry of high intensity in the range of $3100-3250 \mathrm{~cm}^{-1}$ in Raman spectra of Fe(II)P, calculated in our work (Fig. 2, Table). The most intense mode 105 $\left(v_{\text {calc }}=3247 \mathrm{~cm}^{-1}, I=1038.8 \dot{\mathrm{A}}^{4} /\right.$ a.m.u. $)$ is determined by symmetrical stretching motions $\mathrm{C}_{\beta}-\mathrm{H}$ and $\mathrm{C}_{\beta}-\mathrm{H}$, occurring in one phase in all the pyrrole rings. Polarization ratio, calculated for this mode, equals 0.128 , i.e. this band of Raman spectra is highly polarized. In Raman spectra of $\mathrm{H}_{2} \mathrm{P}$ this type of vibrations is observed at the same frequency, yet it has lower intensity (605.3 $\dot{\mathrm{A}}^{4} /$ a.m.u.), but the stretching 
$\mathrm{C}_{\beta}-\mathrm{H}$ motions occur only in protonated pyrrole rings. In the close-lying vibrational mode 102 of the $\mathrm{Fe}(\mathrm{II}) \mathrm{P}$ molecule $\left(v_{\text {calc }}=3246 \mathrm{~cm}^{-1}, I=331.1 \dot{\mathrm{A}}^{4} /\right.$ a.m.u. $)$, vibrations of $\mathrm{C}_{\beta}-\mathrm{H}$ and $\mathrm{C}_{\beta}-\mathrm{H}$ bonds occur in the out-of-phase fashion; the calculated depolarization ratio is rather high $(\rho=0.740)$. InRaman spectra this band should be depolarized. In the $D_{4 h}$ point group of the $\mathrm{ZnP}$ molecule this mode corresponds to the $b_{l g}$ symmetry with the similar frequency and intensity $[3$, 8]. $\mathrm{In}_{2} \mathrm{P}$ this mode corresponds to vibration of $\mathrm{C}_{\beta}-\mathrm{H}$ bonds in non-protonated rings; our calculated data show that it has lower frequency, but almost two times higher intensity (Table). Next to intense band (102, 105 ) in Raman spectra of Fe(II)P there are two groups of closely-located bands $(94,97$, and 98, 100). Bands (100 and 98) at 3223 and $3222 \mathrm{~cm}^{-1}$ form a weak shoulder (Fig. 2), they correspond to asymmetrical vibrations of $\mathrm{C}_{\beta}-\mathrm{H}$ and have $b_{I g}$ symmetry type in $D_{2 h}$ group. Modes $a_{2 g}$ and $b_{2 g}$ in a more symmetrical $D_{4 h}$ group correspond to them, respectively. The first one is prohibited in Raman spectra of $\mathrm{ZnP}$ molecule [3, 8], but it becomes strongly allowed in $\mathrm{Fe}(\mathrm{II}) \mathrm{P}$ molecule $(I=$ $\dot{A}^{4} /$ a.m.u.). The analysis of these bands in the fine-structure Raman spectra of Fe(II)P crystals could be a reliable criterion in determination of structural deviations from the $D_{4 h}$ symmetry.

Vibrational mode 97 with $a_{g}$ symmetry is highly polarized $(\rho=0.132)$. It is determined by vibrations of the $\mathrm{C}_{\mathrm{m}}-\mathrm{H}$ bonds in methine bridges, occurring in one phase in the Fe(II)P molecule. The present calculations suggest that position of this vibrational mode in the spectrum and its intensity are not affected by introduction of the $\mathrm{Fe}^{2+}$ ion into coordination centre of the molecule. Band 94, the degenerate analogue, is depolarized and less intense.

Intermediate region of Raman spectra. Middle part of Raman spectra of porphins was thoroughly investigated in experiments. We predicted a group of vibrational modes of $a_{g}$ symmetry and low-intensity mode 92 of $b_{l g}$ symmetry in the range of 1500-1650 $\mathrm{cm}^{-1}$ frequencies in Raman spectra. Mode 93 is mainly determined by asymmetrical stretching motions of $\mathrm{C}_{\mathrm{m}}-\mathrm{C}$ bonds of methine bridges and related deformational vibrations of $\mathrm{C}_{\mathrm{m}} \mathrm{H}$. These vibrations have a large amplitude, they occur in one phase in positions $\alpha, \beta, \gamma$, and $\delta$. In Raman spectra of $\mathrm{H}_{2} \mathrm{P}$ this type of vibrations corresponds to frequency of 1643 $\mathrm{cm}^{-1}$ and intensity of $203.4 \dot{\mathrm{A}}^{4} /$ a.m.u., close to values for $\mathrm{Fe}(\mathrm{II}) \mathrm{P}\left(1650 \mathrm{~cm}^{-1}\right.$ and $195.9 \dot{\mathrm{A}}^{4} /$ a.m.u. $)$.

In experimental Raman spectra of $\mathrm{H}_{2} \mathrm{P}$ this band is observed at $1609 \mathrm{~cm}^{-1}[2,18]$, and in fluorescence spectrum - at $1614 \mathrm{~cm}^{-1}$ [19]. The ratio of $v_{\text {exper }} / v_{\text {calc }}$ for this vibrational mode of $\mathrm{H}_{2} \mathrm{P}$ and many other modes, equal to $\approx 0.98$, allowed correcting the majority of frequencies, calculated for $\mathrm{Fe}(\mathrm{II}) \mathrm{P}$ in interim range of Raman spectra.

To take into account systematic errors in the course of frequency calculation for the stretching motions of $\mathrm{C}-\mathrm{H}$ bonds (in the high-frequency range) we introduced the scaling factor 0.96, vibrational frequencies in the range of $145-756 \mathrm{~cm}^{-1}$ were corrected by the introduction of scaling factor $0.99\left(v_{\text {corr }}\right.$ is a corrected frequency value). Asymmetric stretching motion $\mathrm{C}_{\mathrm{m}}-\mathrm{C}$ gives a depolarized band inRaman spectra (calculated $\rho=0.659$ ), found experimentally in Raman spectra of a number of FeOEP derivatives [11]. Its shift to the range of lower frequencies correlates with the increase of the $\mathrm{Fe}-\mathrm{N}$ distance in complexes.

Polarized bands of Raman spectra, revealed in the range of $1475-1510 \mathrm{~cm}^{-1}$ for a number of FeOEP derivatives, were assigned by Kitagawa et al. [11] to the totally symmetrical $\mathrm{C}_{\mathrm{m}}-\mathrm{C}$ stretching motion. Our data prove that polarized mode $89 \mathrm{Fe}(\mathrm{II}) \mathrm{P}(\rho=0.110)$ really includes the $v_{\mathrm{s}}\left(\mathrm{C}_{\mathrm{m}}-\mathrm{C}\right)$ vibration, but the main contribution into this mode is made by stretching motions $\mathrm{C}_{\beta}-\mathrm{C}_{\beta}\left(\mathrm{C}_{\beta}-\mathrm{C}_{\beta}\right)$ and $\mathrm{C}_{\alpha}-\mathrm{N}\left(\mathrm{C}_{\alpha^{\prime}}-\mathrm{N}\right)$, occurring in all pyrrole ring in one phase $\left(v_{\text {calc }}=1578 \mathrm{~cm}^{-1}, v_{\text {corr }}=\right.$ $\left.1546 \mathrm{~cm}^{-1}\right)$. InRaman spectra of $\mathrm{H}_{2} \mathrm{P}$ molecule, the 89 mode of $\mathrm{Fe}(\mathrm{II}) \mathrm{P}$ corresponds to mode 91 [3] with a higher frequency $\left(v_{\text {calc }}=1590 \mathrm{~cm}^{-1}\right)$ and with less intensity (Table).

Similar to the mode 89 , the mode 86 with calculated frequency of $1523 \mathrm{~cm}^{-1}$ consists of vibrations of $\mathrm{C}_{\beta}-\mathrm{C}_{\beta}$ bond $\left(\mathrm{C}_{\beta}-\mathrm{C}_{\beta}\right)$ and symmetrical vibrations of $\mathrm{C}_{\alpha}-\mathrm{N}\left(\mathrm{C}_{\alpha^{\prime}}-\mathrm{N}\right)$, but vibrations in the II and IV pyrrole rings are in the out-of-phase fashion to vibrations in the I and III pyrrole rings. According to calculations, this mode has depolarization character $(\rho$ $=0.733)$, therefore, it will correlate with the $b_{I g}$ vibrations in the $D_{4 h}$ group. The amplitude of vibrations of the $\mathrm{C}_{\alpha^{\prime}}-\mathrm{N}$ bonds in $\mathrm{Fe}(\mathrm{II}) \mathrm{P}$ is considerably smaller than that of $\mathrm{C}_{\alpha}-\mathrm{N}$. The calculated intensity for this 
mode (405.3 $\dot{\mathrm{A}}^{4}$ /a.m.u.) in Fe(II)P has the highest value in the observed range of frequencies; as for $\mathrm{H}_{2} \mathrm{P}$, the same regularity is observed with smaller differences in Raman intensities.

We also predicted three vibrational modes of $a_{g}$ symmetry in the range of $1300-1500 \mathrm{~cm}^{-1}$, but they are less intense (Fig. 2, Table). Polarized $(\rho=0.145)$ mode $82\left(v_{\text {calc }}=1457 \mathrm{~cm}^{-1}, I=95.8 \dot{\mathrm{A}}^{4} /\right.$ a.m.u. $)$ consists of stretching motions of $\mathrm{C}_{\beta}-\mathrm{C}_{\beta}\left(\mathrm{C}_{\beta^{\prime}}, \mathrm{C}_{\beta^{\prime}}\right)$ and $\mathrm{C}_{\alpha}-\mathrm{N}\left(\mathrm{C}_{\alpha^{\prime}}-\mathrm{N}\right)$, occurring in one phase in all pyrrole rings, and of symmetrical vibrations of $\mathrm{C}_{\mathrm{m}}-\mathrm{C}$ bonds in one phase in all methine bridges. The amplitude of vibrations of $\mathrm{C}_{\alpha}-\mathrm{N}$ bonds is less than that of $\mathrm{C}_{\alpha^{\prime}}-\mathrm{N}$, while values for $\mathrm{C}_{\beta}-\mathrm{C}_{\beta}$ are higher that those for $\mathrm{C}_{\beta^{\prime}}-\mathrm{C}_{\beta^{\prime}}$. Similar regularity was noted in the corresponding mode of $\mathrm{H}_{2} \mathrm{P}$. Depolarized band $(\rho=0.733)$, calculated at $1417 \mathrm{~cm}^{-1}$ (mode 80$)$ is more intense $\left(I=186.5 \dot{\mathrm{A}}^{4} /\right.$ a.m.u.) Like mode 82 , it belongs to stretching motions of pyrrole rings bonds, but vibrations in rings II and IV take place in out-of-phase to I and III. In this mode stretching motions are mingled with deformational vibrations of $\mathrm{C}_{\mathrm{m}} \mathrm{H}$ groups of methine bridges of large amplitude. According to calculations, the last band $a_{g}$ in this spectral range (mode $76, v_{\text {calc }}=1360 \mathrm{~cm}^{-1}$ ) may be described as stretching motions of $\mathrm{C}_{\alpha}-\mathrm{N}$ and $\mathrm{C}_{\alpha}-\mathrm{C}_{\beta}$, taking place in one phase in all pyrrole rings, with strong displacement of $\mathrm{C}_{\alpha}\left(\mathrm{C}_{\alpha^{\prime}}\right)$ and $\mathrm{N}$ atoms, simultaneous deformation of pyrrole rings and considerable bending motions of $\mathrm{C}_{\alpha} \mathrm{C}_{\mathrm{m}} \mathrm{C}_{\alpha^{\prime}}$ and $\mathrm{CC}_{\mathrm{m}} \mathrm{H}$, which, in its turn, conditions movement of $\mathrm{C}_{\mathrm{m}} \mathrm{H}$-groups with a large amplitude.

Calculated depolarization ratio $(\rho=0.195)$ is much smaller than that for $\mathrm{H}_{2} \mathrm{P}(\rho=0.444)$, i.e. in $\mathrm{Fe}(\mathrm{II}) \mathrm{P}$ this type of vibrations is more polarized due to the fact that deviations from the $D_{4 h}$ symmetry of the $\mathrm{Fe}(\mathrm{II}) \mathrm{P}$ molecule are not so significant as those for $\mathrm{H}_{2} \mathrm{P}$, telling considerably on the latter. Vibrations of $b_{l g}$-type (except mode 77) in this range are of extremely low intensity (Table) which differs considerably from the behaviour of these vibrations in $\mathrm{H}_{2} \mathrm{P}$ molecule.

Five vibrational modes of $a_{g}$ symmetry should be observed in Raman spectra in the range of frequencies of 950-1200 $\mathrm{cm}^{-1}$. The main contribution into mode 69 $\left(v_{\text {calc }}=1196 \mathrm{~cm}^{-1}\right)$ is made by rocking motions of $\mathrm{C}_{\mathrm{m}} \mathrm{H}$-groups. There are also vibrations of $\mathrm{Fe}-\mathrm{N}$ bonds without displacement of $\mathrm{Fe}$ atom in this mode. It is noteworthy that displacement of Fe atom is completely absent in vibrations in Raman spectra, as it violated symmetry of inversion (these vibrations are assigned to ungerade type; they may be active only in IR spectrum). Mode 89 is depolarized ( $\rho=0.745)$, therefore, this type of vibrations in $D_{4 h}$ group will correlate with $b_{l g}$ mode of symmetry. The main contribution into polarized $(\rho=0.109)$ mode $65\left(v_{\text {calc }}=\right.$ $\left.1107 \mathrm{~cm}^{-1}\right)$ is made by rocking motions of $\mathrm{C}_{\beta} \mathrm{H}$ and $\mathrm{C}_{\beta} \mathrm{H}$ groups; its calculated intensity is not very high $(9.1$ $\dot{\mathrm{A}}^{4}$ /a.m.u.). In $\mathrm{H}_{2} \mathrm{P}$ molecule vibrations $r\left(\mathrm{C}_{\beta} \mathrm{H}\right)$ in the corresponding mode take place only in protonated pyrrole rings.

Similar to mode 65 , mode $64\left(v_{\text {calc }}=1102 \mathrm{~cm}^{-1}, I=\right.$ $4.2 \dot{\mathrm{A}}^{4}$ /a.m.u.) has a large contribution of vibrations of $r\left(\mathrm{C}_{\beta} \mathrm{H}\right)$ and $r\left(\mathrm{C}_{\beta} \mathrm{H}\right)$, and stretching motions of $\mathrm{C}_{\beta}-\mathrm{C}_{\beta}$ and $\mathrm{C}_{\beta^{\prime}}-\mathrm{C}_{\beta^{\prime}}$ bonds out-of-phase, which results in considerable depolarization of mode in Raman spectra $(\rho=0.582)$. Therefore, mode 65 in metalloporphyrins of the $D_{4 h}$ symmetry group should correlate with the corresponding mode of the $a_{l g}$ symmetry, and mode 64 - with $b_{l g}$. However, comparison to the calculated Raman spectra of $\mathrm{ZnP}$ molecule showed that the mode 65 in $\mathrm{Fe}$ (II)P correlates with the low-intensity mode $b_{l g}$ in $\mathrm{ZnP}$. The reason of polarization of mode 65 is not clear. This is the only deviation from the simple symmetry rules in Raman spectra for metalloporphyrins of the $D_{4 h}$ - and $D_{2 h}$-type, found by us while comparing calculations of $\mathrm{ZnP}, \mathrm{Fe}(\mathrm{II}) \mathrm{P}$, and $\mathrm{H}_{2} \mathrm{P}$ molecules. Though intensity of this band in Raman spectra is not high, it deserves special investigation.

The last intense band in this range (about 1020 $\left.\mathrm{cm}^{-1}\right)$ is conditioned by overlapping of modes 55, 56, 60 (Fig. 2). Analysis of the data in Table shows that these modes are rather selective regarding $\mathrm{Fe}(\mathrm{II})$ ion, it is especially true about polarized mode $60(\rho=0.125)$, whose frequency is displaced $-17 \mathrm{~cm}^{-1}$ in $\mathrm{H}_{2} \mathrm{P}$, and 57 $\mathrm{cm}^{-1}$ in $\mathrm{ZnP}$.

The main input into mode 60 is made by symmetrical stretching motions of $\mathrm{C}_{\alpha}-\mathrm{C}_{\beta}$ and $\mathrm{Fe}-\mathrm{N}^{33(34)}$ with strong displacement of atoms of $\mathrm{N}^{33(34)}$ and $\mathrm{C}_{\beta} \mathrm{H}$-groups. Similar vibrations are observed in rings II and IV, but their amplitude is smaller. Corresponding mode in $\mathrm{H}_{2} \mathrm{P}$ molecule is observed in non-resonance Raman spectra at $987 \mathrm{~cm}^{-1}$, while in resonance Raman spectra, phosphorescence and fluorescence spectra it is 
seen at $988 \mathrm{~cm}^{-1}$ [2] and is conditioned by stretching motions of $\mathrm{C}_{\alpha}-\mathrm{C}_{\beta}$ in protonated pyrrole rings. In mode 55 vibrations of $\mathrm{Fe}-\mathrm{N}$ and $\mathrm{C}_{\alpha}-\mathrm{C}_{\beta}$ with a large amplitude are observed in rings II and IV; this mode in $\mathrm{H}_{2} \mathrm{P}$ molecule correlates with vibrations of $\mathrm{C}_{\alpha}-\mathrm{C}_{\beta}$ bonds in non-protonated pyrrole rings. Modes 60 and 55 in Fe(II)P molecule are polarized in Raman spectra ( $\rho=$ 0.125 and 0.119 respectively). We believe that considerable differences in intensities of vibrational modes $60-55$ in $\mathrm{Fe}(\mathrm{II}) \mathrm{P}$ and $\mathrm{H}_{2} \mathrm{P}$ molecules pertain to strong displacement of $\mathrm{N}$ atoms in these vibrations.

Frequency window in the range of $1000-750 \mathrm{~cm}^{-1}$ is observed in Raman spectra of many porphyrins [8]. In this frequency range there are out-of-plane vibrations of $\mathrm{CH}$-groups of pyrrole rings and methine bridges, as well as in-plane (twist) motions of the same groups with very low intensity, thus, they are almost not seen in Raman spectra. Out-of-plane modes 52 and 51, 48 and 47, 39 and 40 of $b_{2 g}$ and $b_{3 g}$ symmetry form corresponding quasi-degenerate pairs. In point group of $D_{4 h}$ symmetry modes of $b_{2 g}$ and $b_{3 g}$ type are united into degenerate modes of $e_{g}$ type ([4], Table). Twist motions of $\mathrm{CH}$-groups are related to twisting of pyrrole rings (modes 45 and 43 of $b_{l g}$ symmetry), besides, there is deformation of rings, conditioned by bending motion of $\mathrm{C}_{\alpha} \mathrm{C}_{\beta} \mathrm{C}_{\beta}\left(\mathrm{C}_{\alpha} \mathrm{C}_{\beta} \mathrm{C}_{\beta}\right), \mathrm{C}_{\beta} \mathrm{C}_{\alpha} \mathrm{N}\left(\mathrm{C}_{\beta}, \mathrm{C}_{\alpha} \mathrm{N}\right)$. Calculated and corrected frequencies and intensities of these modes in Raman spectra are presented in Table.

A weak band in the range of $710-756 \mathrm{~cm}^{-1}$ is conditioned by overlapping of vibrational modes 31 , $32,34,36$. The most intense of them is polarized $(\rho=$ $0.128)$ mode 34 of $a_{g}$ symmetry $\left(v_{\text {calc }}=733 \mathrm{~cm}^{-1}, I=\right.$ 28.6 $\dot{\mathrm{A}}^{4} /$ a.m.u.) This mode has pulsation of the whole macrocycle, related to vibration of $\mathrm{C}-\mathrm{H}$ bonds, occurring in all the pyrrole rings in one phase which also leads to deformation of methane bridges $\left(\delta\left(\angle \mathrm{C}_{\alpha} \mathrm{C}_{\mathrm{m}} \mathrm{C}_{\alpha}\right)\right)$ and strong displacement of bridge $\mathrm{CH}$-groups radially from the centre of molecule. Closely-located mode 36 of $a_{g}$ symmetry is considerably depolarized $(\rho=0.576)$ and its intensity is about 4-times smaller than that of mode 34 . Out-of-plane modes 31 and 32, conditioned by out-of-plane vibrations of CH-groups and deformations of pyrrole rings, form a quasi-degenerate pair of low intensity. Similar to spectrum, calculated by us, (Fig. 2), these modes in experimental Raman spectra of many metalloporphyrins $[8,12,13,20]$ merge into one band. Analogous pairs of quasi-degenerate vibrational modes of low intensity form out-of-plane modes 26 and 27.

Low-frequency range of Raman spectra. As stated before [4], low-frequency range of $\mathrm{Fe}(\mathrm{II}) \mathrm{P}$ spectrum has three extremely weak IR bands at $58\left(b_{l u}\right), 68\left(a_{u}\right)$, and $78 \mathrm{~cm}^{-1}\left(b_{l u}\right)$, which are of high importance for out-of-plane dynamics of the whole molecule. Two following bands $\left(v_{4}=145 \mathrm{~cm}^{-1}\right.$ of $b_{3 g}$ symmetry and $v_{5}=$ $149 \mathrm{~cm}^{-1}$ of $b_{2 g}$ symmetry) are also related to out-of-plane modes; according to selection rules, they are allowed in Raman spectra, but their calculated intensities for non-resonance Raman spectra are very low (Table). In singlet and triplet states of $\mathrm{Fe}(\mathrm{II}) \mathrm{P}$ with $D_{4 h}$ symmetry these bands become degenerate $\left(e_{g}\right.$ symmetry) and have similar frequencies. In $\mathrm{Fe}(\mathrm{II}) \mathrm{P}$ molecule the abovementioned vibrations correspond to the bend of pyrrole rings regarding $\mathrm{C}_{\alpha}-\mathrm{C}_{\alpha}$ axis and twisting of opposite rings. The frequency and low intensity of these vibrations remain in other metalloporphyrins, calculated in the same approximation: $\mathrm{ZnP}\left(146 \mathrm{~cm}^{-1}\right)$ and $\mathrm{MgP}\left(144 \mathrm{~cm}^{-1}\right)$ [3]

Intense peak at $107.7 \mathrm{~cm}^{-1}$ was recently revealed in the spectrum of inelastic scattering of neutrons for free-base porphin [9]. We assign it to $b_{I g}$-vibration, calculated by us in Raman spectra of $\mathrm{H}_{2} \mathrm{P}$ molecule at $100 \mathrm{~cm}^{-1}$ with the $6-311 \mathrm{G}$ basis set (Table); this band was previously revealed in resonance Raman spectra at $109 \mathrm{~cm}^{-1}$ [18], though its assignment to frequency of 87 $\mathrm{cm}^{-1}$, calculated with the $6-311 \mathrm{G}$ basis set*, is dubious [2]. Our data eliminate doubts regarding assignment of this band to in-plane mode $v_{6}$, conditioned by twisting of pyrrole rings (Table). As this mode in Fe(II)P is related to bending of $\mathrm{NFeN}$ angles, it is not surprising that its frequency is strongly displaced to the high-frequency range $\left(v_{\text {calc }}=160 \mathrm{~cm}^{-1}, v_{\text {corr }}=158 \mathrm{~cm}^{-1}\right)$ compared to $\mathrm{H}_{2} \mathrm{P}$, while Raman intensity decreases considerably (from 17.2 to $4.8 \dot{\mathrm{A}}^{4} /$ a.m.u.) Therefore, comparison of data for $\mathrm{H}_{2} \mathrm{P}$ and $\mathrm{Fe}(\mathrm{II}) \mathrm{P}$ allows our clear supposition for a new, not revealed weak Raman band at $158 \mathrm{~cm}^{-1}$ for $\mathrm{Fe}$ (II) porphin. According to our data [3], it should be observed at higher frequencies in other metalloporphyrins: $\mathrm{ZnP}\left(178 \mathrm{~cm}^{-1}\right)$ and $\mathrm{MgP}(221$ $\mathrm{cm}^{-1}$ ). In case of $\mathrm{MgP}$ it was actually observed (239 $\mathrm{cm}^{-1}$ ) in Raman spectra at non-resonance excitation in 
close IR range at the wavelength of $1064 \mathrm{~nm}$ [8]. Quasi-degenerate low-intense modes 8 and 10 (211 and $\left.216 \mathrm{~cm}^{-1}\right), 23$ and $24\left(442\right.$ and $\left.444 \mathrm{~cm}^{-1}\right)$ are conditioned by out-of-plane twisting of pyrrole rings.

The most intense band in low-frequency range of Raman spectra of Fe(II)P is that of strongly polarized $(\rho=0.117)$ mode 18 of $a_{g}$ symmetry $\left(v_{\text {calc }}=370 \mathrm{~cm}^{-1}, I=\right.$ $99.9 \dot{\mathrm{A}}^{4}$ /a.m.u.). This mode is conditioned by stretching motions of Fe-N bonds in one phase which causes pulsation (breathing) of the whole macrocycle. Vibration $v_{18}$ remains as a very intense polarized band in Raman spectra in all metalloporphyrins, calculated by us: $\mathrm{ZnP}\left(373 \mathrm{~cm}^{-1}\right)$ and $\mathrm{MgP}\left(364 \mathrm{~cm}^{-1}\right)$ [3]. Stretching motions of Fe-N bonds out-of-phase form depolarized and less intense band of $a_{g}$-symmetry in Raman spectra at $216 \mathrm{~cm}^{-1}$ (mode 9, $I=27.1 \dot{\mathrm{A}}^{4} /$ a.m.u.). This mode correlates with vibration of $b_{l g}$ symmetry in $D_{4 h}$ group. Vibrations $v_{18}$ and $v_{9}$ include Fe-N bonds, therefore, their frequencies are strongly displaced compared to Raman spectra of $\mathrm{H}_{2} \mathrm{P}$ ( $60 \mathrm{~cm}^{-1}$ to the region of high frequencies).

Conclusions. The performed calculations proved reliability of the DFT B3LYP/6-311G method in prediction of frequencies of active vibrations in Raman spectra of free-base porphin and metalloporphyrins. Forms of vibrations in Raman spectra remain unchanged during formation of the Fe(II)P complex from the porphin molecule (only the NH-vibration bands vanish); considerable changes are mainly observed in frequencies and (or) intensities of those vibrational modes in case if there is strong displacement of nitrogen atoms during vibrations (modes 6, 9, 18, 55, 56, 60, 75, 77, 78, etc). Comparison of data for the $\mathrm{H}_{2} \mathrm{P}$ and $\mathrm{Fe}(\mathrm{II}) \mathrm{P}$ molecules allowed prediction of a new weak band at $158 \mathrm{~cm}^{-1}$ in Raman spectra of $\mathrm{Fe}(\mathrm{II})$ porphin. As this vibrational mode has contribution of $\mathrm{NFeN}, \mathrm{FeNC}_{\alpha}$ deformational vibrations, it should be very sensitive to the structure of Fe-porphyrin, its spin, and oxidation degree as well as to dynamics of energy transfer in enzymatic reactions. Correction of the calculated vibration frequencies ofRaman spectra of Fe(II)P was performed on the basis of the ratio of experimental values of frequencies to theoretical ones, calculated for porphin molecule. Calculated depolarization parameters for the plane-polarized incident light allowed symmetry prediction of active vibrations in Raman spectra of metalloporphyrins with the $D_{4 h}$ point group, which is important for assignments in their Raman spectra.

The possibility of applying the methods of quantum mechanics regarding large molecules to simulate vibrational spectra is of great importance to the vibrational spectroscopy. It is possible that in the near future the theoretical methods would be as important for vibrational spectroscopy as the experimental ones. Investigation in the sphere of spectroscopy of porphins, performed by present work, proves the DFT method to be promising in simulation of vibrational spectra of hemproteins.

The work is financially supported by the state foundation of fundamental research (DFFD, F26.5/008).

\section{В. А. Минаева, Б. Ф. Минаев, Д. Н. Говорун}

Исследование спектра комбинационного рассеяния $\mathrm{Fe}(\mathrm{II})$-порфина методом функционала плотности

Резюме

Квантово-химическим методом теории функционала плотности проведено моделирование спектра комбинационного рассеяния света (КРC) Fe(II)-порфина в квинтетном (основном) состоянии молекуль. Для оптимизации геометрии и расчета спектра КРС использован неограниченный по спину функционал UB3LYP в базисе 6-311G. Все активные в спектре КРС моды детально проанализированы. Показано, что введение в молекулу порфина иона Fe(II) приводит к значительному изменению частот и интенсивностей колебательных мод в тех случаях, когда при колебании происходит сильное смещение атомов азота. Обсуждается отношение деполяризации КРС для плоскополяризованного падающчего света.

Ключевые слова: Fe(II)-порфин, квинтетное спиновое состояние, теория функиионала плотности, спектр КРС.

\section{В. О. Мінаєва, Б. П. Мінаєв, Д. М. Говорун}

Дослідження спектра комбінаційного розсіяння $\mathrm{Fe}(\mathrm{II})$ - порфіну методом функціоналу густини

Резюме

Квантово-хімічним методом теорії функиіоналу густини змодельовано спектр комбінаційного розсіювання світла (КРС) $\mathrm{Fe}(I I)$-порфіну у квінтетному (основному) стані молекули. Для оптимізаиії геометрії й розрахунку спектра КРС використано необмежений за спіном функиіонал UB3LYP у базисі 6-311G. Всі активні в спектрі КРС моди детально проаналізовано. Показано, що введення в молекулу порфіну іона Fe(II) призводить до значної зміни частот та інтенсивностей коливальних мод у тих випадках, коли при коливанні відбу- 
вається сильне змішення атомів азоту. Обговорюється ступінь деполяризачї КРС для плоскополяризованого падаючого світла.

Ключові слова: Fe(II)-порфін, квінтет, теорія функціоналу густини, спектр КРС.

\section{REFERENCES}

1. Minaev B. F., Minaeva V. A., Vasenko O. M. Calculation of the $\mathrm{Fe}(\mathrm{II})$ porphin spin states by the density functional theory // Ukr. Bioorg. Acta.-2007.-5, N 1.- P. 24-31.

2. Kozlowski P., Jarzecki A., Pulay P., Li X.-Y., Zgierski M. Vibrational assignment and definite harmonic force field for porphine. 2. Comparison with Nonresonance Raman Data // J. Phys. Chem.-1996.-100, N 33.-P. 13985-13992.

3. Minaev B., Agren H. Theoretical DFT study of phosphorescence from porphyrins // Chem. Phys.-2005.-315, N 3.P. 215-239.

4. Minaev B. F., Minaev A. B., Hovorun D. M. Investigation of infrared spectrum of $\mathrm{Fe}(\mathrm{II})$ porphin in different spin states by quantum chemical density functional theory // Biopolymers and Cell.-2007.-23, N 6.-P. 527-536.

5. Kozlowski P. M., Spiro T. G., Berces A., Zgierski M. Z. Low-lying spin states of iron(II) Porphine // J. Phys. Chem. B.-1998.-102, N 14.-P. 2603-2608.

6. Becke A. D. Density-functional thermochemistry. The role of exact exchange // J. Chem. Phys.-1993.-98, N 7.-P. 56485655.

7. Paulat F., Praneeth V. K. K., Nather Ch., Lehnert N. Quantum chemistry-based analyses of the vibrational spectra of five-coordinate metalloporphyrins [M(TPP)Cl] // Inorg. Chem.-2006.-45, N 7.-P. 2835-2856.

8. Jarzecki A., Kozlowski P., Pulay P., Ye B. H., Li X.-Y. Scaled quantum mechanical and experimental vibrational spectra of magnesium and zinc porphyrins // Spectrochim. Acta.1997.-A53, N 8.-P. 1195-1209.

9. Verdal N., Kozlowski P., Hudson B. Inelastic neutron scattering spectra of free base and zinc porphines: A comparison with DFT-based vibrational analysis // J. Phys. Chem. A.-2005.-109, N 25.-P. 5724-5733.

10. Kozlowski P., Jarzecki A., Pulay P. Vibrational assignment and definite harmonic force field for porphine. 1. Scaled quantum mechanical results and comparison with empirical force field // J. Phys. Chem.-1996.-100, N 17.-7007-7013.

11. Ozaki Y., Iriyama K., Ogoshi H., Ochiai T., Kitagawa T. Resonance Raman characterization of iron-chlorin complexes in various spin, oxidation, and ligation states. 1 . Comparative study with corresponding iron-porphyrin complexes // J. Phys. Chem.-1986.-90, N 31.-P. 6105-6112.

12. Соловьев К. Н., Гладков Л. Л., Старухин А. С., Шкирман С. Ф. Спектроскопия порфиринов: колебательные состояния -Минск: Наука и техника, 1985.-415 с.

13. Kitagawa T., Abe M., Ogoshi H. Resonance Raman spectra of octaethylporphyrinato-Ni(II) and meso-deuterated and ${ }^{15} \mathrm{~N}$ substituted derivatives. I. Observation and assignments of nonfundamental Raman lines // J. Chem. Phys.-1978.-69, N 10.-4516-4525.

14. Tunnel I., Rinkevicius Z., Vahtras O., Salek P., Helgaker T., Agren H. Density functional theory of nonlinear triplet response properties with applications to phosphorescence // J. Chem. Phys.-2003.-119, N 21.-P. 11024-11034.

15. Frisch M. J., Trucks G. W., Schlegel H. B. et al. Gaussian 03, Revision C.02.-Wallingford CT, 2004.

16. Huszank R., Horvath O. A heme-like, water-soluble iron(II) porphyrin: thermal and photoinduced properties, evidence for sitting-atop structure // Chem. Commun.-2005.-N 2.P. 224-226.

17. Драго Р. Физические методы в химии.-М.: Мир, 1981.T. $1 .-422 \mathrm{c}$

18. Gladkov L., Gradyushko A., Shulga A., Solovyov K., Starukhin $A$. Experimental and theoretical investigation of infrared spectra of porphin, its deuterated derivatives and their metal complexes // J. Mol. Struct. THEOCHEM.-1978.-45, N 3.P. 463-493.

19. Radziszewski J. G., Waluk J., Nepras M., Michl J. Fourier transform fluorescence and phosphorescence of porphine in rare gas matrixes // J. Chem. Phys.-1991.-95, N 5.-P. 19631969.

20. Li X.-Y., Zgierski M. Porphine force field: in-plane normal modes of free-base porphine. Comparison with metalloporphines and structural implications // J. Phys. Chem.1991.-95, N 11.-P. 4268-4287.

UDC 530.145: $(547+543.42)$ Received 05.10 .07 